\title{
Biodegradation of Terephthalic Acid by Rhodococcus biphenylivorans Isolated from Soil
}

\author{
N. Suwanawat, P. Parakulsuksatid, N. Nitayapat, and W. Sanpamongkolchai
}

\begin{abstract}
Terephthalic acid (TA) is one of the main pollutants in wastewater from the polyester textile industry and extremely harmful to human health and the environment. Eighty-seven isolates were collected from soil around the wastewater basin of a polyester textile manufacturer in Thailand, based on their ability to grow in a minimal salt medium (MSM) containing $1 \mathrm{~g} / \mathrm{L}$ TA as the sole carbon and energy source. Nineteen isolates were found to be TA-degrading bacteria. To obtain more efficient TA-degrading bacteria, the TA concentration in MSM was increased to 2 and $5 \mathrm{~g} / \mathrm{L}$. Isolate N2 showed TA-degrading ability higher than $90 \%$ and was identified as Rhodococcus biphenylivorans according to its morphological and biochemical properties and 16S rDNA sequence analysis. $\mathrm{N} 2$ degraded $99.6 \%$ of $10 \mathrm{~g} / \mathrm{L}$ TA in 5 days. Optimal conditions for TA degradation were $30{ }^{\circ} \mathrm{C}, \mathrm{pH} 7.0$ and $200 \mathrm{rpm}$ shaking speed. Results implied that $R$. biphenylivorans could be useful for future applications in bioremediation of TA in the environment.
\end{abstract}

Index Terms-Terephthalic acid, Polyester textile manufacturer, Biodegradation, Rhodococcus biphenylivorans.

\section{INTRODUCTION}

In Thailand, polyester fiber is an important textile industry representing the highest annual man-made fiber production at $67 \%$ or 611,200 tons in 2015 [1]. The synthesis process from upstream to midstream discharges large volumes of wastewater and solid waste containing terephthalic acid and similar organic compounds as environmental pollutants [2].

Terephthalic acid or benzene-1,4-dicarboxylic acid $\left(\mathrm{C}_{6} \mathrm{H}_{4}(\mathrm{COOH})_{2}\right.$, TA) is a raw material for the production of polyethylene terephthalate (PET) which is used in the plastics and polyester fiber industries [2]. TA is extremely harmful to human health and the environment because of its toxic properties which cause inhibition of microbial growth, bladder cancer and impair renal, liver and testicular functions [3], [4]. Therefore, widespread pollution resulting from TA discharge is closely monitored by the U.S. Environmental Protection Agency [5].

Because of its chemical characteristics, TA cannot be completely broken down and eliminated by natural processes [6]. Previous literature reported physicochemical pretreatments for degrading TA but these methods generate toxic intermediates and sludge as secondary pollutants and, in some cases, the cost of treatment is expensive [7].

Manuscript received August 15, 2018; revised December 5, 2018. This research was supported in part by the Department of Biotechnology, Faculty of Agro Industry, Kasetsart University, Bangkok, Thailand.

The authors are with the Department of Biotechnology, Faculty of Agro Industry, Kasetsart University, Bangkok, Thailand (e-mail: nittikarn.su@gmail.com, pramuk.p@ku.ac.th, faginun@ku.ac.th, fagiwrk@ku.ac.th).
Microbial degradation has recently become an attractive alternative method to remove TA with efficiency depending on the activity of the selected microorganisms. Several of these have been reported to degrade compounds such as Pseudomonas aeruginosa PP4 [8], Rhodococcus pyridinivorans and $R$. rhodochrous [9].

Here, high-capacity TA-degrading aerobic bacteria were isolated and their optimal cultivation conditions were investigated.

\section{MATERIAL AND METHODS}

\section{A. Reagents}

Terephthalic acid (TA) with purity greater than $99 \%$ was purchased from Acros Organics (Geel, Belgium). All other chemicals used were of analytical grade.

\section{B. Medium and Culture Conditions}

The minimal salt medium (MSM) used in this study contained $1 \mathrm{~g} / \mathrm{L} \mathrm{TA}, 3 \mathrm{~g} / \mathrm{L}\left(\mathrm{NH}_{4}\right)_{2} \mathrm{SO}_{4}, 1 \mathrm{~g} / \mathrm{L} \mathrm{KH}_{2} \mathrm{PO}_{4}, 0.2 \mathrm{~g} / \mathrm{L}$ $\mathrm{MgSO}_{4} \cdot 7 \mathrm{H}_{2} \mathrm{O}$ and $0.02 \mathrm{~g} / \mathrm{L} \mathrm{FeSO}_{4} \cdot 7 \mathrm{H}_{2} \mathrm{O}$ with $\mathrm{pH}$ 7.0. The seed medium contained $1 \mathrm{~g} / \mathrm{L}$ TA, $3 \mathrm{~g} / \mathrm{L}\left(\mathrm{NH}_{4}\right)_{2} \mathrm{SO}_{4}, 1 \mathrm{~g} / \mathrm{L}$ $\mathrm{KH}_{2} \mathrm{PO}_{4}, 0.2 \mathrm{~g} / \mathrm{L} \mathrm{MgSO} \cdot 7 \mathrm{H}_{2} \mathrm{O}, 0.02 \mathrm{~g} / \mathrm{L} \mathrm{FeSO}{ }_{4} \cdot 7 \mathrm{H}_{2} \mathrm{O}$ and $0.2 \mathrm{~g} / \mathrm{L}$ yeast extract, adjusted to $\mathrm{pH}$ 7.0. The screening medium contained $1 \mathrm{~g} / \mathrm{L}$ TA, $3 \mathrm{~g} / \mathrm{L}\left(\mathrm{NH}_{4}\right)_{2} \mathrm{SO}_{4}, 1 \mathrm{~g} / \mathrm{L}$ $\mathrm{KH}_{2} \mathrm{PO}_{4}, 0.2 \mathrm{~g} / \mathrm{L} \mathrm{MgSO} \cdot \cdot 7 \mathrm{H}_{2} \mathrm{O}, 0.02 \mathrm{~g} / \mathrm{L} \mathrm{FeSO}_{4} \cdot 7 \mathrm{H}_{2} \mathrm{O}$ and $18 \mathrm{~g} / \mathrm{L}$ agar, adjusted to $\mathrm{pH}$ 7.0. All media were autoclaved at $121{ }^{\circ} \mathrm{C}$ for $15 \mathrm{~min}$. For the liquid media, microbial cultivation was performed at $30{ }^{\circ} \mathrm{C}$ with shaking speed of $200 \mathrm{rpm}$.

\section{Screening and Identification of Bacterial Strain}

Soil samples were collected from the wastewater basin of a polyester textile manufacturer in Nakhon Pathom, Thailand. Ten grams of each soil sample were added to $100 \mathrm{~mL}$ of MSM containing $1 \mathrm{~g} / \mathrm{L}$ TA and incubated for 5 days in an incubator shaker operating at $30{ }^{\circ} \mathrm{C}$ and $200 \mathrm{rpm}$. Then, TA-degrading bacteria were isolated on the screening medium following the serial dilution method and single colonies were obtained by streaking method.

An isolated strain with the highest TA-degrading ability was selected after cultivation on MSM containing 1, 2 and 5 g/L TA.

Morphological and biochemical characteristics of the selected strain were analyzed. DNA extraction and $16 \mathrm{~S}$ rDNA sequence analysis were performed by Macrogen, Inc (Seoul, Korea). Polymerase chain reaction (PCR) was performed using the universal primer pairs of $785 \mathrm{~F}$ (5'-GGATTAGATACCCTGGTA-3')/ 907R (5'-CCGTCA ATTCMTTTRACTTT-3'). Then, the $16 \mathrm{~S}$ rDNA sequence alignment was conducted with MEGA 7.0 software by the 
neighbor-joining method.

\section{Biodegradation Experiments}

The selected strain was cultured on MSM medium containing various TA concentrations $(1,2,5$ and $10 \mathrm{~g} / \mathrm{L}$ of TA) by inoculating $2 \%$ seed culture with a concentration of $2.0 \times 10^{6} \mathrm{CFU} / \mathrm{mL}$ and incubated at $30{ }^{\circ} \mathrm{C}$ and $200 \mathrm{rpm}$ for 5 days.

\section{E. Optimization of Physical Factors for TA Degradation}

An orthogonal $\mathrm{L}_{9}\left(3^{3}\right)$ test design was adopted, including three factors (temperature: $\mathrm{A}, \mathrm{pH}$ : $\mathrm{B}$, and shaking speed: $\mathrm{C}$ ) with three levels (Table I). The selected strain was cultured with MSM containing $1 \mathrm{~g} / \mathrm{L}$ TA by inoculating $2 \%$ seed culture with a concentration of $2.0 \times 10^{6} \mathrm{CFU} / \mathrm{mL}$ for $48 \mathrm{~h}$.

TABLE I: FACTORS AND LEVELS FOR THE ORTHOGONAL DESIGN

\begin{tabular}{lccc}
\hline \multirow{2}{*}{ Factor } & \multicolumn{3}{c}{ Level } \\
\cline { 2 - 4 } \multicolumn{1}{c}{ Femperature $\left({ }^{\circ} \mathrm{C}\right)$} & 30 & 37 & 3 \\
\hline pH value & 7 & 8 & 9 \\
Shaking speed $(\mathrm{rpm})$ & 50 & 100 & 200 \\
\hline \hline
\end{tabular}

\section{F. Analytical Methods}

Measurement of terephthalic acid, based on the characteristic of its aromatic ring structure which can absorb UV light at $240 \mathrm{~nm}$, was performed using a UV-Vis Spectrophotometer (Genesys 10S UV-Vis, Thermo Fisher Scientific) [10]. Concentration of TA was calculated based on a standard calibration graph.

Cell concentration was determined by measuring the optical density at $600 \mathrm{~nm}$.

\section{RESULTS AND DISCUSSION}

\section{A. Bacteria Isolation and Identification}

A total of 87 isolates from soil nearby a wastewater basin of a polyester textile manufacturer located in Nakhon Pathom, Thailand were obtained in MSM containing TA $(1 \mathrm{~g} / \mathrm{L})$ as the sole carbon source. Nineteen isolates showed the ability to degrade $1 \mathrm{~g} / \mathrm{L}$ TA. When TA concentration was increased to 2 and $5 \mathrm{~g} / \mathrm{L}$, only isolate $\mathrm{N} 2$ could grow well with TA degrading ability higher than 90\%. Morphological characteristics of the strain were determined as aerobic, Gram positive, rod-shaped bacilli, non-spore-forming and non-motile. N2 colonies were smooth, pale orange-pink, convex, sticky and opaque with regular edges on the screening medium.

Biochemical characteristics of isolate N2 tested positive for catalase activity but negative for urease activity and indole production (Table II). Isolate N2 was able to utilize fructose, sorbitol, mannitol and arabitol as the sole sources of carbon for energy and growth. This strain also showed esculin hydrolysis activity but could not utilize citrate and malonate as a sole carbon source.

Isolate N2 was closely related to Rhodococcus biphenylivorans (16S rRNA gene sequence identities ranging at $99 \%$ analyzed by Macrogen, Inc). For neighbor-joining analysis, isolate $\mathrm{N} 2$ shared highest similarities with the group of $R$. biphenylivorans TG9, $R$. gordoniae W4937 and $R$. rhodochrous DSM43247T (supported by 83\% bootstrapping) (Fig. 1).

$R$. biphenylivorans is a novel strain identified for the degradation of TA. Previously, $R$. biphenylivorans strain TG9 ${ }^{\mathrm{T}}$ was reported as a Gram-positive aerobic bacterium which was isolated from a polychlorinated biphenyl (PCB)-contaminated site in China [11]. Although this bacterium has not been reported for biodegradation of PCB or other xenobiotics on conventional bacteriological media, the strain was still alive and retained metabolic activity such as naphthalene degradation, bisphenol degradation and polycyclic aromatic hydrocarbon degradation [12]. $R$. biphenylivorans has ring-cleavage pathways for bacterial catabolism of aromatic compounds that support TA degradation.

TABLE II: MORPHOLOGICAL AND BIOCHEMICAL CHARACTERISTICS OF ISOLATE N2

\begin{tabular}{ll}
\hline \hline Characteristic & Result \\
\hline Colonial morphology & $\begin{array}{l}\text { Pale orange-pink appearance with rounded, } \\
\text { convex, sticky, opaque and regular edges }\end{array}$ \\
Gram stain & Positive \\
Cell shape & Rod-shaped bacilli \\
Spore & Non-spore-forming \\
Mobility & Non-motile \\
Catalase activity & Positive \\
Urease activity & Negative \\
Indole production & Negative
\end{tabular}

Utilization as sole carbon source and acid production

Lactose Negative

Xylose Negative

Maltose Negative

Fructose Positive

Dextrose Negative

Galactose Negative

Raffinose Negative

Trehalose Negative

Melibiose Negative

Sucrose Negative

L-Arabinose Negative

Mannose Negative

Inulin Negative

Sodium gluconate Negative

Glycerol Negative

Salicin Negative

Dulcitol Negative

Inositol Negative

Sorbitol Positive

Mannitol Positive

Adonitol Negative

Arabitol Positive

Erythritol Negative

$\propto$-Methyl-D-glucoside Negative

Rhamnose Negative

Cellobiose Negative

Melezitose Negative

$\alpha$-Methyl-D-mannoside Negative

Xylitol Negative

$\beta$-galactosidase activity Negative

Esculin hydrolysis Positive

D-Arabinose Negative

Citrate utilization Negative

Malonate utilization Negative

Sorbose Negative 


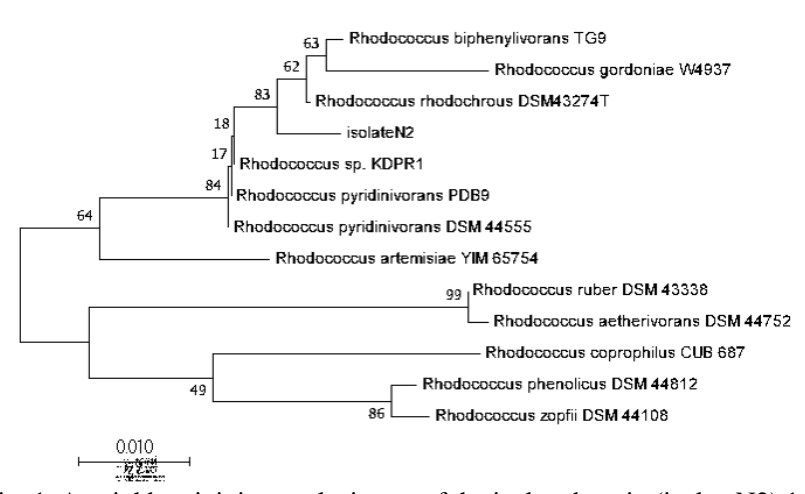

Fig. 1. A neighbor-joining analysis tree of the isolated strain (isolateN2) 16S rDNA.

\section{B. TA Biodegradation Experiments}

The effect of TA concentration $(1,2,5$ and $10 \mathrm{~g} / \mathrm{L})$ on the degrading ability of $R$. biphenylivorans is shown in Fig. 2. At concentrations of up to $5 \mathrm{~g} / \mathrm{L}$, TA was completely degraded within $60 \mathrm{~h}$ while $120 \mathrm{~h}$ was required to completely degrade $10 \mathrm{~g} / \mathrm{L} \mathrm{TA}$. An acclimation of $24 \mathrm{~h}$ was observed at the $10 \mathrm{~g} / \mathrm{L}$ TA concentration.

Increasing the TA concentration decreased the degradation extent, indicating reduced TA-degrading ability of the strain. A high initial TA concentration inhibited cell growth and the ability of the remaining cells to degrade TA [6], [13]. For example, a TA concentration greater than $1 \mathrm{~g} / \mathrm{L}$ inhibited the growth and degrading ability of Pseudomonas sp. [6]. The ability to degrade TA by Arthrobacter sp. 0574 was inhibited when TA concentration was increased above $10 \mathrm{~g} / \mathrm{L}$ [13]. Interestingly, cell growth and TA-degrading ability of $R$. biphenylivorans did not show any inhibitory effect at high concentration of TA such as $10 \mathrm{~g} / \mathrm{L}$, indicating that this strain had a strong ability to degrade TA compared to other reported strains.

\section{Optimization of Physical Factors for TA Degradation}

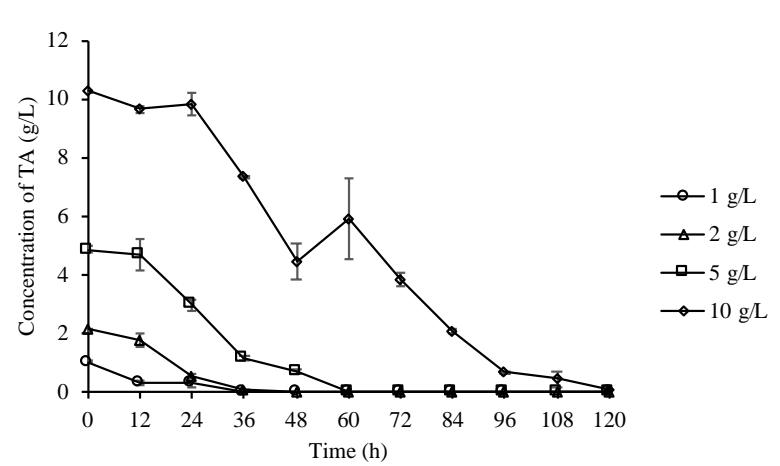

Fig. 2. Time course of TA degradation by $R$. biphenylivorans on various initial TA concentrations

To select the optimal TA degradation conditions, three physical factors (temperature, $\mathrm{pH}$ and shaking speed) were determined using an orthogonal $\mathrm{L}_{9}\left(3^{3}\right)$ test design. A range analysis was performed to determine the effect of the factors. A high range value $(\mathrm{R})$ implies that the factor has a strong effect on the results [14]. The orthogonal test results indicated the ranking order of the three factors that affected TA degrading ability as shaking speed $>$ temperature $>\mathrm{pH}$ as shown in Table III. To confirm which factors had the strongest effect on TA degradation, an analysis of variance
(ANOVA) was carried out and results are shown in Table IV. Findings also indicated that the effect of shaking speed was significantly different $(P<0.05)$. Therefore, shaking speed was the most important factor regarding the rate of TA degradation after cultivation for 48 hours in a medium containing $0.1 \mathrm{~g} / \mathrm{L}$ of TA. For TA degradation, the optimal condition was $30{ }^{\circ} \mathrm{C}$, pH 7 and shaking speed of $200 \mathrm{rpm}$. This was considered the maximum mean value of temperature, $\mathrm{pH}$ and shaking speed from single-factor statistical data and pairwise comparison data (data not shown).

TABLE III: RESULTS OF ORTHOGONAL TEST L9(33) OF THE STRAIN ON RATE OF TA DEGRADATION (\%) FOR 48 HOURS

\begin{tabular}{ccccc}
\hline \hline & \multicolumn{3}{c}{ Factors } & Rate of TA \\
\cline { 2 - 4 } Treatments & $\begin{array}{c}\text { Temperature } \\
\left({ }^{\circ} \mathrm{C}\right), \mathrm{A}\end{array}$ & $\mathrm{pH}, \mathrm{B}$ & $\begin{array}{c}\text { Shaking } \\
\text { speed } \\
(\mathrm{rpm}), \mathrm{C}\end{array}$ & $\begin{array}{c}\text { degradation } \\
(\%)\end{array}$ \\
\hline 1 & 40 & 9 & 50 & 10.0 \\
2 & 30 & 8 & 200 & 99.3 \\
3 & 40 & 7 & 200 & 99.4 \\
4 & 30 & 9 & 100 & 99.4 \\
5 & 37 & 9 & 200 & 99.6 \\
6 & 40 & 8 & 100 & 98.4 \\
7 & 37 & 8 & 50 & 28.0 \\
8 & 37 & 7 & 100 & 99.4 \\
9 & 30 & 7 & 50 & 39.0 \\
$\mathrm{~K}_{1}$ & 79.2 & 79.3 & 25.8 & \\
$\mathrm{~K}_{2}$ & 75.7 & 75.2 & 99.1 & \\
$\mathrm{~K}_{3}$ & 69.4 & 69.8 & 99.4 & \\
$\mathrm{R}$ & 9.87 & 9.50 & 73.7 & \\
Ranking & $\mathrm{C}>\mathrm{A}>\mathrm{B}$ & & & \\
\hline \hline
\end{tabular}

$\mathrm{K}_{\mathrm{i}}=$ The average values of degradation rate for level $\mathrm{i}=1,2,3$

$\mathrm{R}=\mathrm{K}_{\mathrm{i}} \max -\mathrm{K}_{\mathrm{i}}$ min; larger $\mathrm{R}$ value indicating more significant effects

TABLE III: VARIANCE ANALYSIS OF ORTHOGONAL EXPERIMENT OF THE STRAIN ON RATE OF TA DEGRADATION (\%) FOR 48 HOURS

\begin{tabular}{lccccc}
\hline \hline \multicolumn{1}{c}{ Variables } & $\begin{array}{c}\text { Sum of } \\
\text { Squares }\end{array}$ & df & $\begin{array}{c}\text { Mean } \\
\text { Square }\end{array}$ & F-value & Sig. \\
\hline Temperature, A & 149.762 & 2 & 1847.661 & 1.119 & 0.472 \\
$\mathrm{pH}, \mathrm{B}$ & 136.402 & 2 & 50295.538 & 1.019 & 0.495 \\
Shaking speed, C & 10799.802 & 2 & 74.881 & 80.670 & 0.012 \\
Error & 133.876 & 2 & 66.938 & & \\
\hline \hline $\mathrm{R}^{2}=.988$ (Adjusted $\left.\mathrm{R}^{2}=0.952\right)$ & & & &
\end{tabular}

$\mathrm{R}^{2}=.988$ (Adjusted $\mathrm{R}^{2}=0.952$ )

\section{CONCLUSION}

We initially identified a Rhodococcus biphenylivorans as an attractive bacterial strain for use in microbial biodegradation of TA in TA concentrations up to $10 \mathrm{~g} / \mathrm{L}$. The effect of physical factors (temperature, $\mathrm{pH}$ and shaking speed) on TA degradation were investigated and the optimal conditions for degradation were found to be temperature 30 ${ }^{\circ} \mathrm{C}$, pH 7.0 and shaking speed $200 \mathrm{rpm}$ for 48 hours. To further develop and utilize this bacterium, the metabolic pathways or its mechanism, kinetic parameter for its growth and degradation, toxicity and others need to be studied.

\section{REFERENCES}

[1] Thailand textile institute (THTI), Thai Textile Statistic 2015/2016, Thailand Textile Institute, Bangkok: THTI, 2016, ch. 2, pp. 11-18.

[2] A. Ordaz-Cortés, F. Thalasso, E. Salgado-Manjarrez, and C. Garibay-Orijel, "Treatment of wastewater containing high concentrations of terephthalic acid by Comamonas sp. and 
Rhodococcus sp.: kinetic and stoichiometric characterization," Water Environ. J. vol. 28, pp. 393-400, September 2014.

[3] G. Dai, L. Cui, L. Song, N. Gong, J. Chen, and R. Zhao, "Terephthalic acid occupational exposure and its effect on organ functions in fiber workers," Environ. Toxicol. Pharm., vol. 20, pp. 209-214, July 2005.

[4] Z. Zhang, L. Ma, X. X. Zhang, W. Li, Y. Zhang, and B. Wu, "Genomic expression profiles in liver of mice exposed to purified terephthalic acid manufacturing wastewater," J. Hazard Mater., vol. 181, pp. 1121-1126, September 2010.

[5] US Environmental Protection Agency (US EPA). (March 2018). Substance Registry Services (SRS): Terephthalic acid. [Online]. Available:

https://iaspub.epa.gov/sor_internet/registry/substreg/searchandretrieve /advancedsearch/externalSearch.do?p_type $=$ CASNO\&p_value $=100-2$ $1-0 \#$

[6] Z. J. Wang, L. H. Teng, and J. F. Zhang, "Study on optimal biodegradation of terephthalic acid by an isolated Psuedomonas sp.," Afr. J. Biotechnol., vol. 10, no. 16, pp. 3143-3148, April 2011.

[7] M. O. Daramola, E. F. Aransiola, and A. G. Adeogun, "Comparative study of thermophilic and mesophilic anaerobic treatment of purified terephthalic acid (PTA) wastewater," Nat. Sci., vol. 3, pp. 371-378, January 2011.

[8] C. Vamsee-Krishna, Y. Mohan, and P. S. Phale, "Biodegradation of phthalate isomers by Pseudomonas aeruginosa PP4, Pseudomonas sp. PPD and Acinetobacter lwoffii ISP4," Appl. Microbiol. Biotechnol., vol. 72, pp. 1263-1269, October 2006.

[9] S. Sookkasem, "Isolation and Screening of Terephthalic acid (TA)-degrading microorganisms from textile industry," M.S. thesis, Dept. Biotech., Kasetsart Univ., Bangkok, Thailand, 2013.

[10] T. Kimura and Y. Ito, "Two bacterial mixed culture systems suitable for degrading terephthalate in waste water," J. Biosci. Bioen, vol. 91, no. 4, pp. 416-418, January 2001.

[11] X. Su, Y. Liu, M. Z. Hashmi, J. Hu, L. Ding, M. Wu, and C. Shen, "Rhodococcus biphenylivorans sp. nov., a polychlorinated biphenyl-degrading bacterium," Antonie Leeuwenhoek, vol. 107, pp. 55-63, January 2015.

[12] X. Su, F. Sun, Y. Wang, M. Z. Hashmi, L. Guo, L. Ding, and C. Shen, "Identification, characterization and molecular analysis of the viable but nonculturable Rhodococcus biphenylivorans," Scientific Reports, 2015.

[13] Y. M. Zhang, Y. Q. Sun, Z. J. Wang, and J. Zhang, "Degradation of terephthalic acid by a newly isolated strain of Arthrobacter sp. 0574," $S$ Afr. J. Anim. Sci., vol. 109, pp. 1-4, January 2013.

[14] J. Zhou, R. An, H. Zhang, and Y. Liu, "Orthogonal design of pharmaceutical experiment based on SPSS," in Proc. ICICA 2012, Chengde, China, September 14-16, 2012, pp. 552-560, 2012.

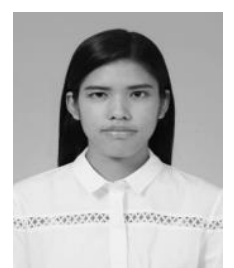

Nittikarn Suwanawat was born on December $24^{\text {th }}$ 1992 and graduated with a bachelor's degree in biotechnology from Kasetsart University, Bangkok, Thailand in 2015. She is currently a double master's degree student in the Department of Biotechnology, Kasetsart University and in the Division of Applied Life Sciences, Graduate School of Agriculture, Kyoto-University. Her current research interests include enzyme technology, environmental biotechnology and molecular microbial science.

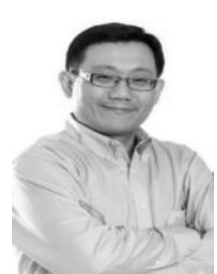

Pramuk Parakulsuksatid obtained his master's degree in biological system engineering from Virginia Polytechnic Institute and State University. He received a $\mathrm{Ph} . \mathrm{D}$. in food science \& technology from Mississippi State University, USA

$\mathrm{He}$ is currently an assistant professor in Department of Biotechnology, Kasetsart University, Bangkok, Thailand.

His current research interests include biochemical engineering and enzyme technology.

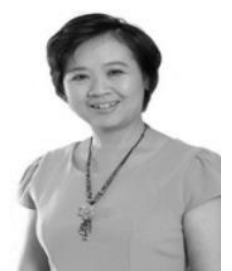

Nuttakan Nitayapat obtained her master's and Ph.D. degree in environmental science from University of Strathclyde. She received a Ph.D. in environmental biotechnology from University of Strathclyde.

She is currently an assistant professor in Department of Biotechnology, Kasetsart University, Bangkok, Thailand. Her current research interests include decolorisation of dyestuffs and melanoidins, anaerobic digestion and biological wastewater treatment.

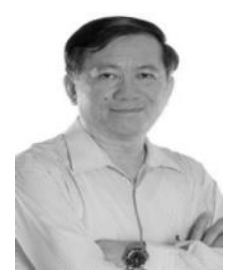

Werasit Sanpamongkolchai graduated with the bachelor's degree in food science and technology from Kasetsart University, Thailand in 1980 and obtained his master's degree in applied microbiology from Kagoshima University, Japan in 1983. He received a $\mathrm{Ph} . \mathrm{D}$. in applied microbiology from Kyushu University, Japan in 1986.

$\mathrm{He}$ is currently an associate professor in the Department of Biotechnology, Kasetsart University, Bangkok, Thailand. His current research interests include enzyme technology, industrial fermentation, rice utilization and environmental biotechnology. 